\title{
Childhood Kidney Disorder
}

National Cancer Institute

\section{Source}

National Cancer Institute. Childhood Kidney Disorder. NCI Thesaurus. Code C84448.

A kidney disorder that appears during childhood. 